\title{
Narzędzia polityki fiskalnej wspierające innowacyjność małych i średnich przedsiębiorstw w Polsce
}

Fiscal policy tools supporting the innovativeness of small and medium-sized enterprises in Poland

\section{Wprowadzenie}

Obecnie jednym z największych wyzwań stojących przed polską gospodarką jest podnoszenie poziomu jej innowacyjności. $Z$ uwagi na duże znaczenie sektora małych i średnich przedsiębiorstw (dalej: MSP) w Polsce innowacyjność całej gospodarki jest od niego zależna. Z tego powodu badanie innowacyjności sektora MSP jest uzasadnione. Zarówno polityka unijna, jak i krajowa kładzie nacisk na pobudzenie inwestycji w nowe rozwiązania w sektorze prywatnym. Państwo może tworzyć odpowiednie warunki sprzyjające rozwojowi działalności innowacyjnej m.in. poprzez zachęty fiskalne.

Celem pracy jest przedstawienie zagadnienia innowacyjności i analiza jej poziomu w MSP w Polsce oraz wskazanie narzędzi polityki fiskalnej wspierających działalność innowacyjną przedsiębiorstw. Praca opiera się na przeglądzie literatury oraz raportach Polskiej Agencji Rozwoju Przedsiębiorczości, Głównego Urzędu Statystycznego i KPMG.

\section{Pojęcie i pomiar innowacyjności}

W ciągu ostatnich kilku dekad wprowadzono kilka definicji innowacji. We współczesnym świecie pojęcie to jest niezwykle obszerne. Termin ma swój początek w łacińskim słowie innovatio, które w tłumaczeniu na język polski oznacza odnowienie. Często pojęcie innowacyjności definiuje się również jako 
łacińskie słowo novus oznaczające nowość (Kopaliński, 2007). Warto zwrócić uwagę na objaśnienie pojęcia innowacji zasugerowane przez Schumpetera (1960). Przedstawia on innowację jako główne zjawisko w rozwoju gospodarczym, będące połączeniem kapitału oraz środków produkcji, obejmujące swoim zasięgiem pięć następujących kombinacji: stworzenie nowego produktu bądź wprowadzenie na rynek towarów o oryginalnych właściwościach; zastosowanie nowatorskiej metody produkcji; znalezienie nowego rynku zbytu; pozyskanie nieznanych źródeł surowców; wprowadzenie nowych struktur rynkowych w organizacji przemysłowej. W prosty sposób innowacje tłumaczy Kahn (2018). Autorka uważa, że jest to po prostu wprowadzenie czegoś nowego. Kuratko (2009) definiuje je jako proces, $w$ którym przedsiębiorcy przekształcają szanse w idee zbywalne. Drucker (2014) natomiast prezentuje innowację jako czyn, który nadaje zasobom nową zdolność do tworzenia bogactwa. Kreatywność i jej efekty tworzą innowacje, które są zamierzonym zastosowaniem w organizacji nowych dla niej pomysłów, produktów oraz procedur (Schippers i in., 2015). Definicja prezentowana w podręczniku Oslo Manual wskazuje, że innowacje to „nowy bądź ulepszony produkt lub proces (lub ich połączenie), znacznie różniące się od tych już istniejących w jednostce, który został udostępniony potencjalnym użytkownikom lub zastosowany w praktyce gospodarczej przez jednostkę" (OECD, 2018). Podobne kryteria przedstawia Gault (2018), podkreślając potrzebę ujednolicenia definicji w celu zwiększenia przejrzystości w ocenie innowacyjności organizacji. Jedne z najnowszych publikacji dotyczące innowacyjności w czasie pandemii Covid-19 określają innowacje jako kluczowy sposób zaspokojenia złożonych, a często konkurujących ze sobą potrzeb społecznych w trudnych chwilach (Dahlke i in., 2021). Zimmerling i Chen (2021) przedstawiają innowację jako twórczą odpowiedź na dyskretne wydarzenie, w tym przypadku pandemię koronawirusa, wymagającą zaangażowania zasobów organizacji w rozwój nowych produktów lub procesów. Jak wskazuje Bogdanienko (1998), ,innowacje decydują o konkurencyjności przedsiębiorstwa, to znaczy o jego zdolności do utrzymania się na rynku. I dlatego nie jest prawdziwe twierdzenie, że wprowadzanie innowacji jest ryzykowne - odwrotnie, to brak innowacji może stanowić zagrożenie dla bytu przedsiębiorstwa”. Z uwagi na to, że przedsiębiorstwa dążą do poprawy produktywności i zapewnienia trwałego wzrostu, będą musiały zwiększyć swoje zdolności do innowacji (OECD, 2018).

Szansą dla przedsiębiorstw na wyróżnienie się od konkurencji jest wprowadzanie innowacyjnych produktów, usług, procesów lub modeli biznesowych dostosowanych do nisz (Porter, 1980). Jeśli innowacja ustanowi wysokie bariery, uniemożliwiając konkurentom wejście na rynek, pozycja firmy w branży zo- 
stanie wzmocniona, a innowacja może skutkować ponadprzeciętnymi zyskami (Porter, 1985). Innowacje są ważne dla wzrostu i rentowności firmy. Szybkość i częstotliwość wdrażania innowacji ma kluczowe znaczenie dla rozwoju i sukcesu szczególnie MSP (Hilmersson i Hilmersson, 2021). Dzięki innowacjom przedsiębiorstwa mogą przetrwać w coraz bardziej niekorzystnym środowisku konkurencyjnym. Ponadto w związku z wystąpieniem kryzysu Covid-19 wskazuje się, że dzięki innowacjom podmioty będą mogły lepiej zaspokoić potrzeby konsumentów oraz będą siłą napędową trwałego sukcesu przedsiębiorstwa (Ebersberger i Kuckertz, 2021).

Popularność innowacyjności jako jednego z elementów rozwoju przedsiębiorstwa skutkowała wzrostem zainteresowania jej pomiaru. Jednak do tej pory nie opracowano jednego syntetycznego wskaźnika. Istnieje wiele metod pomiaru, często bardzo złożonych (Motyka, 2011). Przykładem mogą być tutaj mierniki innowacyjności gospodarek, m.in. Summary Innovation Index będący zbiorem 27 wskaźników (European Commision, 2020); Global Innovation Index składający się z 80 wskaźników (Cornell University, INSEAD, World Intellectual Property Organization, 2020); Bloomberg Innovation Index złożony z 7 wskaźników szczegółowych (www.bloomberg.com). Innowacyjność przedsiębiorstwa można oceniać na podstawie liczby i rodzaju innowacji wdrożonych w danym okresie, wartości sprzedaży nowych lub istotnie ulepszonych produktów, a także miar odwołujących się do praw własności intelektualnej (Pichlak, 2012). Do ostatniej grupy można zaliczyć wskaźniki dotyczące m.in. liczby dokonanych przez firmę zgłoszeń patentowych, udzielonych praw wyłącznych, wielkości utrzymywanego portfela patentów, cytowań patentów, zakresu terytorialnego ochrony itp. (Neuhäusler i in., 2011). Najczęściej stosowaną miarą innowacyjności przedsiębiorstwa jest liczba posiadanych patentów oraz ich cytowań, wskaźniki te uznawane się obecnie jako standard (Seru, 2014; Chemmanur i in., 2018, 2020; Hall, 2019 lub Elings, 2020). Duża popularność miar opartych na statystykach patentowych wynika $\mathrm{z}$ łatwego dostępu do niezbędnych danych przez urzędy patentowe. Autorzy podręcznika Oslo Manual podkreślają potrzebę ujednolicenia mierników innowacji. W tym celu nawiązano współpracę z Międzynarodową Organizacją Normalizującą (ISO) - Komitetem Technicznym ds. zarządzania innowacjami (OECD, 2018). Jednolity zestaw mierników innowacyjności stosowany przez przedsiębiorstwa umożliwiłby porównania pomiędzy konkurencją oraz przyczyniłby się do rozwoju odpowiednich standardów rynkowych.

Wpływ innowacji na przedsiębiorstwo może dokonywać się zarówno w sposób bezpośredni, jaki i pośredni. Ponadto efekty wdrożonych innowacji mogą być odroczone w czasie. Wielu autorów wskazuje na większe znaczenie wyko- 
rzystania innowacji w działalności niż sam fakt ich wdrożenia (Desyllas i Sako, 2013; Jabłoński, 2013). Z drugiej strony przedsiębiorstwa muszą liczyć się także z niebezpieczeństwem przedostania się wiedzy dotyczącej istotnych innowacji do konkurencji, co w efekcie może prowadzić np. do obniżenia rentowności sprzedaży (Czarnitzki i Kraft, 2012).

Badania na temat innowacyjności przedsiębiorstw w Polsce dotyczą głównie oceny poziomu innowacyjności czy uwarunkowań działań innowacyjnych (Janasz i in, 2002; Mazur-Wierzbicka, 2015; Romanowska, 2016; Stawicka, 2017; Wiśniewska, 2018). Ze względu na stosunkowo niski poziom innowacyjności polskich przedsiębiorstw uzasadnione jest podejmowanie tego zagadnienia.

\section{Analiza stanu sektora MSP w Polsce}

Sektor MSP, czyli firm zatrudniających mniej niż 250 osób i których roczny obrót nie przekracza $50 \mathrm{mln}$ euro, a/lub całkowity bilans roczny nie przekracza $43 \mathrm{mln}$ euro (WE, 2008), odgrywa ogromną rolę w gospodarce krajowej. Odpowiada za wytworzenie blisko 50\% polskiego PKB i zatrudnienie prawie $7 \mathrm{mln}$ ludzi (PARP, 2020b). Sektor MSP w gospodarce spełnia funkcje społeczne, polityczne i gospodarcze. Jest niezbędny do zrównoważonego funkcjonowania gospodarki (Szczepaniak, 2009). MSP stanowią 99,8\% wszystkich przedsiębiorstw w Polsce. Mimo to sektor ten ma nadal duży potencjał rozwojowy ze względu na niewielkąliczbę firm przypadających na jednego mieszkańca i mniejszy wkład w generowanie PKB niż wynosi średnia unijna (58\%) (ec.europa.eu). Gospodarka jeszcze nie nasyciła się tego typu firmami. Wśród polskich MSP dominują firmy usługowe i handlowe (rys. 1).

Wyzwania, przed którymi stoi opisywany sektor, to brak kapitału, trudności w zdobyciu wykwalifikowanej kadry, niski zysk, brak technologii i know-how (Hasan i Almubarak, 2016). Dodatkowo przeszkody, jakie stoją przed polskimi firmami, to obciążenia podatkowe, biurokracja, rzadziej korupcja czy problem $\mathrm{z}$ dostępem do odpowiedniej infrastruktury. Największą przeszkodą dla rozwoju MSP jest „pułapka na małą skalę”. (Sawicki, 2019). Przedsiębiorstwa te koncentrują się przede wszystkim na działaniach o zasięgu lokalnym, mają wysoki poziom awersji do ryzyka i luk w umiejętnościach zarządczych. Pomimo tego są motorem wzrostu gospodarczego głównie dzięki innowacjom i działaniom przedsiębiorczym. Uważa się, że MSP szybciej przyjmują innowacje, a co za tym idzie, mają lepsze zdolności przedsiębiorcze (Nasution i in., 2011).

W ramach sektora MSP w Polsce istnieje zróżnicowanie poziomu innowacyjności ze względu na rozmiar przedsiębiorstwa. Odsetek firm innowacyjnych 


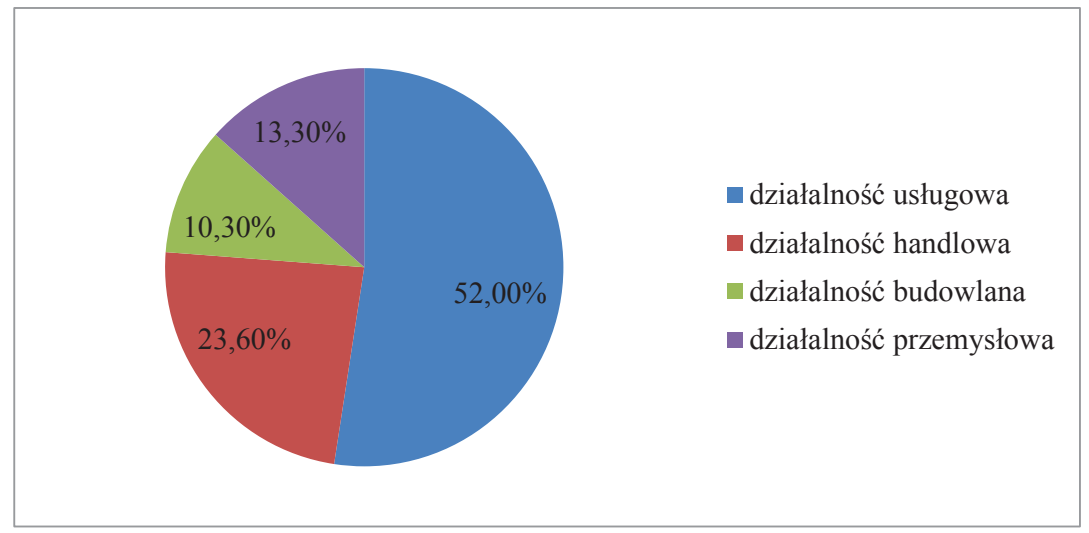

Rysunek 1. Struktura branżowa polskich przedsiębiorstw

Źródło: opracowanie własne: PARP, Raport o stanie sektora małych $i$ średnich przedsiębiorstw w Polsce 2020.

jest silnie skorelowany z wielkością firmy i jest istotnie wyższy w średnich niż małych i mikroprzedsiębiorstwach. Zgodnie $\mathrm{z}$ danymi przedstawionymi w raporcie PARP (2020a) „Monitoring innowacyjności polskich przedsiębiorstw. Wyniki III edycja badania" odsetek innowacyjnych firm mikro to $29,2 \%$, małych $-38,7 \%$, natomiast średnich - 43,3\%. Mikro i małe firmy zwykle mają problemy ze sfinalizowaniem swoich projektów innowacyjnych. Działalność innowacyjna przedsiębiorstw polega głównie na nakładach w środki materialne. Skala tego rodzaju działalności jest podobna w przypadku mikro i małych firm (64\% i 65\%) i jest znacznie wyższa w przypadku średnich przedsiębiorstw (80\%). Wraz ze wzrostem wielkości firmy rośnie również odsetek firm ponoszących nakłady na szkolenia (odpowiednio 40\%, 48\%, 66\%). Podobnie sytuacja wygląda w przypadku prowadzenia wewnętrznych prac badawczo-naukowych $(18 \%, 21 \%, 32 \%)$ oraz zakupu zewnętrznych B+R $(9 \%, 12 \%, 19 \%)$. W przypadku podejmowania współpracy z innymi podmiotami taką kooperację deklaruje 44\% mikroprzedsiębiorstw, 55\% małych firm i 58\% średnich. Mikro i małe firmy przyjmują zachowawczą postawę wobec innowacji, ponieważ poprzez wzorowanie się na rozwiązaniach wprowadzanych przez większych konkurentów minimalizują ryzyko działalności. Dodatkowo mikroprzedsiębiorstwa wierzą, że podejmowanie działalności innowacyjnej nie jest niezbędne do zdobycia przewagi konkurencyjnej. Co ciekawe, 52\% mikroprzedsiębiorstw deklaruje dużą bądź średnią potrzebę pozyskania środków publicznych na sfinansowanie swojej działalności innowacyjnej w porównaniu z 65\% małych i $68 \%$ dużych firm. Wydawać by się mogło, że w przypadku mniejszych możliwości 
finansowych to mikrofirmy będą potrzebować większego dofinansowania zewnętrznego (2020a). Może to wynikać z charakteru procesu innowacyjnego w mikroprzedsiębiorstwach, który zwykle jest nieskomplikowany, krótki i rzadko stanowi nowość dla rynku. Generalnie innowacyjność sektora MSP w Polsce jest stosunkowo niska. Należy podkreślić, że duży wpływ ma na to znaczący udział mikroprzedsiębiorstw (97\%) w całym sektorze MSP. Chociaż szczegółowe dane finansowe dotyczące tych firm są trudno dostępne ze względu na posługiwanie się uproszczonym modelem ewidencji księgowej, mikroprzedsiębiorstwa charakteryzują się niższymi możliwościami finansowymi, ale wyższą rentownością niż duże firmy. Pomimo przeznaczania znacznie mniejszych środków na działalność innowacyjną wprowadzają innowacje, głównie produktowe. Wskazuje się jednak, że są to innowacje odtworzeniowe, będące nowością jedynie w skali przedsiębiorstwa (Decyk i Juchniewicz, 2016).

Zgodnie z raportem PARP (2020b) jedynie 22\% przedsiębiorstw wdrożyło innowacje w latach 2016-2018. Wyższym stopniem innowacyjności cechują się firmy przemysłowe (24\%) niż usługowe (19,6\%). Warto podkreślić, że średnie przedsiębiorstwa wprowadzają innowacje częściej niż małe firmy. Do najbardziej innowacyjnych branż w Polsce należy zaliczyć: ubezpieczenia, reasekurację oraz fundusze emerytalne, z wyłączeniem obowiązkowego ubezpieczenia społecznego (77,6\% firm innowacyjnych), badania naukowe i prace rozwojowe (58,5\%), produkcję wyrobów farmaceutycznych (52\%), produkcję komputerów, wyrobów elektronicznych i optycznych $(51,6 \%)$, produkcję chemikaliów i wyrobów chemicznych (45,5\%) oraz działalność związaną z oprogramowaniem i doradztwem w zakresie informatyki (43,5\%). Najmniej innowacyjne branże to: transport lądowy i rurociągowy $(12,7 \%)$ oraz rekultywacja $(7,4 \%)$. Ochrona własności intelektualnej w Polsce w sektorze MSP jest na bardzo niskim poziomie. Tylko średnio $4 \%$ firm przemysłowych i usługowych zgłasza do ochrony swoje znaki towarowe. Mniejsze przedsiębiorstwa często napotykają na poważne utrudnienia w dostępie do systemu patentowego, przede wszystkim ze względu na brak środków na pokrycie kosztów związanych z ochroną oraz ograniczone możliwości skutecznego egzekwowania posiadanych praw wyłącznych (Holgersson, 2013). Nakłady na działalność innowacyjną różnią się w zależności od rodzaju przedsiębiorstwa. Firmy przemysłowe wydają więcej środków, które przeznaczają głównie na środki trwałe. W przypadku przedsiębiorstw usługowych przeważają nakłady na działalność badawczo-rozwojową. Wydatki na B+R w 2018 r. wynosiły w Polsce 1,21\% PKB. Udział wydatków przedsiębiorstw w tym wskaźniku wynosi ponad $50 \%$, co wskazuje na wysokie zaangażowanie sektora prywatnego w działalność innowacyjną 
w Polsce (Ziętek-Kwaśniewska, 2020). MSP częściej niż duże firmy korzystają z kredytów bankowych, ale rzadko ubiegają się o pożyczki w walutach obcych. $\mathrm{Z}$ dostępnych danych wynika, że innowacje w sektorze MSP są w głównej mierze opłacane ze środków własnych (66\%). Mały udział (7\%) wydatków innowacyjnych pokrywany jest ze środków otrzymanych od instytucji krajowych dysponujących środkami publicznymi (tab. 1).

Tabela 1. Źródła finansowania działalności innowacyjnej sektora MSP w Polsce w 2018 r.

\begin{tabular}{|c|c|c|c|c|c|c|c|}
\hline 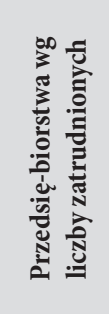 & 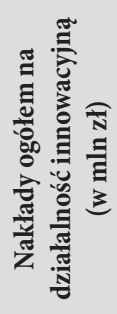 & 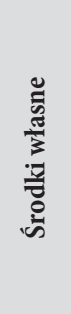 & 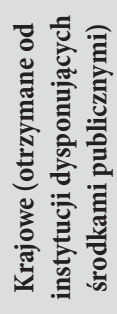 & 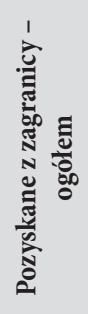 & 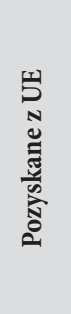 & 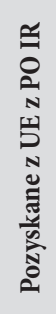 & 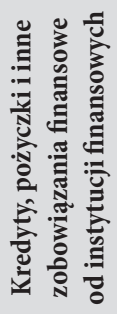 \\
\hline Ogółem & 9812,2 & $66 \%$ & $7 \%$ & $14 \%$ & $13 \%$ & $7 \%$ & $11 \%$ \\
\hline $10-49$ & 3672,7 & $60 \%$ & $9 \%$ & $19 \%$ & $18 \%$ & $9 \%$ & $9 \%$ \\
\hline $50-249$ & 6139,5 & $71 \%$ & $4 \%$ & $9 \%$ & $9 \%$ & $5 \%$ & $12 \%$ \\
\hline
\end{tabular}

Źródło: opracowanie własne: PARP, Raport o stanie sektora małych i średnich przedsiębiorstw w Polsce 2020.

\section{Narzędzia wspierające dziatalność innowacyjną przedsiębiorstw z sektora MSP w Polsce}

Kwestia innowacyjności jest ważna zarówno z punktu widzenia państwa, jak i przedsiębiorcy. Innowacje sprzyjają rozwojowi społeczno-gospodarczemu i stanowią podstawowy element budowania przewagi konkurencyjnej. Realizując założenia polityki innowacyjnej, państwo może przyczynić się do budowania postaw przedsiębiorczych i innowacyjnych zarówno w sposób bezpośredni, jak i pośredni. Najbardziej doraźnymi formami wspomagania innowacyjności są instrumenty finansowe (Zuzek i Paluch, 2016).

Najpopularniejszymi formami wsparcia bezpośredniego są dotacje i granty, czyli finansowe wsparcie przez instytucje krajowe zarządzające środkami publicznymi określonych zadań. W Polsce dotacje dla MSP przyznawane są zwykle w drodze konkursu. Instytucje dokonujące wsparcia w tym zakresie to głównie Polska Agencja Rozwoju Przedsiębiorczości, Polski Fundusz Rozwoju, Narodowe Centrum Nauki, Narodowe Centrum Badań i Rozwoju oraz Bank Gospodarstwa Krajowego. MSP mogą otrzymywać również środki finansowe w ramach grantów 
pochodzących z Regionalnych Programów Operacyjnych, stworzonych w każdym z 16 województw w Polsce. Dotacje przeznaczone na innowacje w 2021 r. mają na celu przede wszystkim rozwój współpracy pomiędzy przedsiębiorstwami a jednostkami naukowo-badawczymi („Bony na innowacje”), dofinansowanie projektów, w ramach których zostanie opracowany nowy produkt lub usługa („Szybka ścieżka”), ale również ułatwienie wdrożenia wyników prac B+R („Badania na rynek”, „Kredyt na innowacje technologiczne”) (PARP, 2020b).

Równie skutecznym narzędziem proinnowacyjnym może być polityka podatkowa. Odpowiednie regulacje często skłaniają przedsiębiorców do przeznaczania sporej części zysków na innowacje, które w normalnych warunkach byłyby opodatkowane. Instrumenty podatkowe są jedną z form uczestniczenia państwa w kosztach działalności innowacyjnej przedsiębiorstw (Zegarowicz, 2016). Najbardziej popularne, proinnowacyjne regulacje podatkowe na świecie to: zwolnienia podatkowe, ulga podatkowa, przyśpieszona amortyzacja aktywów $\mathrm{B}+\mathrm{R}$, obniżona stawka podatku, odliczenie od podatku, wakacje podatkowe odliczenie od podstawy opodatkowania oraz zwrot podatku VAT (tab. 2)

Tabela 2. Wykorzystanie zachęt podatkowych na innowacje w zależności od rodzaju instrumentu

\begin{tabular}{|l|c|c|}
\hline \multicolumn{1}{|c|}{ Rodzaj instrumentu } & Liczba krajów (47) & Odsetek krajów \\
\hline Zwolnienia podatkowe & 30 & $64 \%$ \\
\hline Ulga podatkowa & 28 & $60 \%$ \\
\hline Przyśpieszona amortyzacja aktywów B+R & 19 & $40 \%$ \\
\hline Obniżona stawka podatku & 19 & $40 \%$ \\
\hline Odliczenia od podatku & 16 & $34 \%$ \\
\hline Wakacje podatkowe & 12 & $26 \%$ \\
\hline Odliczenie od podstawy opodatkowania & 5 & $11 \%$ \\
\hline Zwrot podatku VAT & 3 & $6 \%$ \\
\hline
\end{tabular}

Źródło: opracowanie własne: EY. (2020). Worldwide ReDD Incentives Reference Guide, https://www.ey.com/ en_gl/tax-guides/worldwide-r-and-d-incentives-reference-guide-2020.

System wspierania innowacji w Polsce przy pomocy podatków nie jest rozbudowany. Należałoby wymienić tu ulgę na badania i rozwój wprowadzoną w $2016 \mathrm{r}$. (ustawa z dnia 25 września 2015 r. o zmianie niektórych ustaw w związku ze wspieraniem innowacyjności Dz.U. 2015, poz. 1767). Ulga polega na odliczeniu od podstawy opodatkowania, czyli wydatków poniesionych na prowadzenie działalności $B+R$ przez przedsiębiorstwo. Relatywnie niskie stawki odliczeń, wynoszące zaledwie od 10 do 30\% kosztów kwalifikowanych, wpływają na niekorzyść tej ulgi. Do skorzystania z odliczenia uprawnieni są podatnicy opodatkowani podatkiem CIT oraz skalą podatkową i podatkiem liniowym w ramach PIT. 
Z ulgi można skorzystać maksymalnie przez 3 lata po roku poniesienia wydatków. Dodatkowym wymogiem jest prowadzenie badań na podstawie umowy z jednostką naukową oraz odrębna ewidencja kosztów działalności badawczo-rozwojowej. Zwrot poniesionych nakładów jest podstawą do utraty prawa do odliczenia. Z ulgi nie mogą skorzystać podatnicy prowadzący działalność na terenie Specjalnej Strefy Ekonomicznej (Janiszewska i Janiszewski, 2020). Doświadczenia państw, które stosują ulgi na działalność badawczo-rozwojową, pokazują, że jest to ważny element wspierania innowacyjności przedsiębiorstw (Zegarowicz, 2016). Kolejnym proinnowacyjnym rozwiązaniem podatkowym w Polsce jest wprowadzone w 2019 r. preferencyjne opodatkowanie (5\%) dochodów uzyskiwanych z praw własności intelektualnej, zwane Innovation Box (IP Box). Do skorzystania z IP Box są uprawnieni wszyscy podatnicy podatku dochodowego od osób prawnych i fizycznych. Ważne jest, że dochód musi pochodzić z praw wytworzonych, rozwiniętych bądź ulepszonych przez podatnika w ramach prowadzonej przez niego działalności badawczo-rozwojowej (MF, 2019). W związku z wystąpieniem pandemii Covid-19 rządzący przygotowali pakiet rozwiązań wspierających m.in. polskie przedsiębiorstwa. Firmy mogą ubiegać się o bezzwrotne pożyczki, wznowienie kredytu obrotowego, dotację z funduszy PFR, wsteczne rozliczenie strat podatkowych w PIT i CIT, odroczenie terminu płatności podatku lub rozłożenie go na raty, zwolnienie ze składek ZUS. Bezpośrednio w zakresie wspierania innowacyjności państwo oferuje przedsiębiorcom korzystniejsze warunki kredytu na innowacje technologiczne oraz skorzystanie z ulgi B+R i IP Box na etapie obliczania zaliczek w przypadku realizowania działań niezbędnych do przeciwdziałania Covid-19 (II filar..., 2021).

Kolejną formą wsparcia innowacyjności przez państwo są zamówienia publiczne. To dzięki nim państwo może być wiodącym konsumentem i użytkownikiem, stanowiąc przykład dla sektora publicznego. Realizacja zamówień publicznych na innowacyjne projekty pozwala odzyskać przedsiębiorstwom koszty związane w opracowaniem i wdrożeniem ryzykownych rozwiązań innowacyjnych. Zamówienia publiczne dotyczące innowacji to procesy, w których instytucje publiczne składają zamówienia na nowe produkty, usługi bądź ich połączenia. Rozwój i dyfuzja tych procesów wywierają wpływ na kierunek i tempo zmian technologicznych i innych procesów innowacyjnych (Zabala-Iturriagagoitia, 2012). Prace badawczo-rozwojowe mogą być finansowane bezpośrednio z zachowaniem zasad konkurencyjności bądź pośrednio np. poprzez wyższą cenę zamawianych produktów lub usług. Zamówienia publiczne mogą być wykorzystane do tworzenia popytu na innowacje, tym samym do zachęcenia przedsiębiorstw do wzrostu poziomu aktywności działalności badawczo-rozwojowej 
(Kardas, 2016). Zagadnienie dotyczące zamówień publicznych jest ustalone prawnie w Porozumieniu ws. Zamówień rządowych z 1994 r. (rewizja w 20014 r.). Państwa członkowskie Unii Europejskiej musiały dostosować krajowe przepisy regulujące to zagadnienie zgodnie z dyrektywą 2004/18/WE. W Polsce zamówienia publiczne reguluje ustawa z dnia 11 września 2019 r. - Prawo zamówień publicznych (Dz.U. 2019 r., poz. 2019). Działania podejmowane przez Polskę w ramach zamówień publicznych mające na celu wspieranie innowacyjności nie były realizowane na szeroką skalę. Miały one bardziej charakter promocyjny $\mathrm{i}$ informacyjny. Wiązały się przede wszystkim z projektami realizowanymi przez Komisję Europejską (Kardas, 2016).

Polityka unijna kładzie duży nacisk na rozwój innowacyjności w każdym państwie członkowskim, stwarzając inteligentną i zrównoważoną gospodarkę sprzyjającą włączeniu społecznemu. Finansowane projekty mają na celu przede wszystkim udostępnienie wyników badań, tak aby przełożyć innowacyjne pomysły na produkty i usługi, które będą sprzyjać wzrostowi gospodarczemu i stwarzaniu nowych miejsc pracy. Celem Unii Europejskiej jest stworzenie jednolitego rynku, który będzie przyciągał innowacyjne przedsiębiorstwa. W związku z tym wdrożono szereg różnych środków z zakresu ochrony patentowej, standaryzacji, zamówień publicznych i inteligentnych regulacji. UE zakłada również pobudzanie innowacji w sektorze prywatnym (PE, 2020). W latach 2014-2020 Polska mogła wykorzystać 82,5 mld euro Funduszy Europejskich. Przedsiębiorcy pozyskiwali środki unijne w ramach następujących programów ogólnopolskich: Inteligentny Rozwój; Infrastruktura i Środowisko; Wiedza, Edukacja, Rozwój; Polska Cyfrowa; Polska Wschodnia oraz 16 programów regionalnych. Kluczowe znaczenie dla sektora MSP stanowiły programy regionalne, Polska Wschodnia i Inteligentny Rozwój. Pomoc unijna ma charakter bezzwrotnych dotacji lub zwrotnych instrumentów finansowych (kredyty, pożyczki preferencyjne). Kolejna strategia unijna, przewidziana na lata 2021-2027, „Horyzont Europa” ma na celu wzmocnienie bazy naukowej i technologicznej oraz europejskiej przestrzeni badawczej, zwiększenie zdolności w zakresie innowacyjności i konkurencyjności, realizację priorytetów obywateli i utrzymanie modelu społeczno-gospodarczego. Pieniądze przewidziane na realizację tych zamierzeń wynoszą 100 mld euro. Środki finansowe będą przeznaczane na wsparcie znaczących i przełomowych inwestycji, które są zbyt ryzykowne dla podmiotów prywatnych - 70\% budżetu zostanie przekazane dla MSP. Badania naukowe i innowacje mają być lepiej powiązane z potrzebami społeczeństwa oraz możliwie w największym stopniu rozpowszechnione (otwarty dostęp do publikacji) (KE, 2020). 
Dotychczasowe badania dotyczące znajomości dostępnych form wspierania innowacyjności w Polsce oraz ich wykorzystania (KPMG 1 , 2019; Ayming², 2019) wskazują, że 77\% badanych przedsiębiorstw ma wiedzę dotyczącą ulgi na badania i rozwój, 37\% firm słyszało o Innovation Box, ale aż 20\% podmiotów nie wie nic na temat dostępnych zachęt. Wykorzystanie dostępnych narzędzi deklaruje jedynie $22 \%$ przedsiębiorstw (15\% korzysta z ulgi B+R, 2\% z IP Box, 5\% z innych form), 46\% firm planuje w przyszłości skorzystać z programów wsparcia innowacyjności. Jako czynniki, które demotywują firmy do skorzystania z ulgi najczęściej, wskazywano: niepewność i zmienność przepisów prawa, brak przejrzystych przepisów oraz obawę o zakwestionowanie wysokości zastosowanego odliczenia. Z drugiej strony $97 \%$ firm, które zastosowały już ulgę B+R, pozytywnie ocenia jej mechanizm, 84\% deklaruje kontynuowanie korzystania, 31\% firm przeznacza środki uzyskane dzięki uldze na dalsze badania i rozwój, a tylko $28 \%$ badanych wskazuje, że dokumentowanie procesu $\mathrm{B}+\mathrm{R}$ jest najtrudniejsze w rozliczeniu ulgi. Niewątpliwie znajomość dostępnych form wsparcia stoi na niskim poziomie. Wpływ na to może w głównej mierze wywierać krótki czas funkcjonowania narzędzia Innovation Box. Należy zauważyć, że firmy, które korzystały z dostępnych form wsparcia działalności innowacyjnej, pozytywnie oceniają te narzędzia, a uzyskane dzięki nim środki wykorzystują na dalszy rozwój.

\section{Zakończenie}

Przegląd literatury pozwala stwierdzić, że innowacyjność jest postrzegana jako jedno z kluczowych źródeł przewagi konkurencyjnej i warunek niezbędny do przetrwania zarówno państwa, jak i przedsiębiorstwa. Programy krajowe i unijne kładą nacisk na pobudzanie aktywności innowacyjnej sektora prywatnego. Szczególną uwagę przywiązuje się do współpracy pomiędzy przedsiębiorstwami a jednostkami naukowo-badawczymi. Sektor MSP odgrywa w polskiej gospodarce znaczącą rolę. Jednak boryka się z wieloma problemami. Są to przede wszystkim niewielkie możliwości finansowe, brak wykwalifikowanej kadry oraz nowych technologii. Działalność innowacyjna małych i średnich firm musi być

1 Badanie zostało przeprowadzone w styczniu 2019 r. przez firmę Norstat Polska metodą wywiadów telefonicznych CATI wśród 150 przedsiębiorstw o przychodach powyżej $30 \mathrm{mln}$ zł, prowadzących działalność badawczo-rozwojową.

2 Badanie zrealizowano od 30 kwietnia do 19 czerwca 2019 r. przez firmę Kantar metodą wywiadów telefonicznych CATI wśród 30 przedsiębiorstw, które rozliczyły ulgę $\mathrm{B}+\mathrm{R}$ w latach 2016-2019. 
wspierana poprzez proinnowacyjną politykę państwa. W Polsce istnieje coraz więcej zachęt do prowadzenia działalności innowacyjnej. Najpopularniejszą formą wsparcia bezpośredniego są dotacje. Ponadto państwo oferuje również zachęty podatkowe. Dodatkowo polskie przedsiębiorstwa mogą korzystać ze środków unijnych przeznaczonych na innowacyjność. Jest to aspekt, na który władze unijne kładą duży nacisk, a nowa perspektywa finansowa „Horyzont Europa” na lata 2021-2027 przewiduje zwiększenie finansowania działań innowacyjnych, które przełożą się na rozwój całej wspólnoty.

Niewątpliwie wzrost innowacyjności sektora MSP w Polsce jest niezbędny do rozwoju całej gospodarki. Decydenci polityczni powinni kreować pozytywną politykę innowacyjną, aby zapewnić przedsiębiorstwom odpowiednie warunki do wykorzystania pełnego potencjału innowacyjności małych i średnich przedsiębiorstw.

\section{Bibliografia}

Ayming. (2019). Ulga B+R, Małymi krokami do większej innowacyjność. Pobrano z https:// www.ayming.pl/wp-content/uploads/sites/16/2019/09/Raport-Ayming-Ulga-BR-2019.pdf (31.01.2021).

Bogdanienko, J. (red.). (1998). Zarzadzanie innowacjami: wybrane problemy: praca zbiorowa. Warszawa: Szkoła Główna Handlowa.

Chemmanur, T. J., Gupta, M., Simonyan, K. (2020). Top Management Team Quality and Innovation in Venture-Backed Private Firms and IPO Market Rewards to Innovative Activity. Entrepreneurship Theory and Practice.

Chemmanur, T.J., Loutskina, E., Tian, X. (2014). Corporate Venture Capital, Value Creation, and Innovation. Review of Financial Studies, 27 (8), 2434-2473.

Cornell University, INSEAD, World Intellectual Property Organization. (2020). Global Innovation Index 2020: who will finance innovation?.

Czarnitzki, D., Kraft, K. (2012). Spillovers of innovation activities and their profitability. Oxford Economic Papers, 64 (2), 302-322.

Dahlke, J., Bogner, K., Becker, M., Schlaile, M. P., Pyka, A., Ebersberger, B. (2021). Crisis-driven innovation and fundamental human needs: A typological framework of rapid-response COVID-19 innovations. Technological Forecasting and Social Change, 169, 120799.

Decyk, K., Juchniewicz, M. (2016). Cechy innowacji oraz źródła pomysłów działalności innowacyjnej mikroprzedsiębiorstw. Przegląd Organizacji, 11, 15-20.

Desyllas, P., Sako, M. (2013). Profiting from business model innovation: Evidence from Pay-As-You-Drive auto insurance. Research Policy, 42 (1), 101-116.

Drucker, P. (2014). Innovation and entrepreneurship. Routledge. 
Ebersberger, B., Kuckertz, A. (2021). Hop to it! The impact of organization type on innovation response time to the COVID-19 crisis. Journal of Business Research, 124, 126-135.

ec.europa.eu

Elings, G. (2020). The relationship between R\&D expenditures, patents granted and firm performance in European high-tech industries. Radboud University.

European Commission. (2020). European Innovation Scoreboard 2020. Methodology Report.

EY. (2020). Worldwide R\&D Incentives Reference Guide. Pobrano z https://www. ey.com/en_gl/tax-guides/worldwide-r-and-d-incentives-reference-guide-2020 (04.05.2021).

Gault, F. (2018). Defining and measuring innovation in all sectors of the economy. Research policy, 47(3), 617-622.

Hall, B. H. (2019). Is there a role for patents in the financing of new innovative firms? Industrial and Corporate Change. Oxford University Press 28, 3, 657-680.

Hasan, F. S., Almubarak, M. M. S., Ahmed, A. (2016). Factors influencing women entrepreneurs' performance in SMEs. World Journal of Entrepreneurship, Management and Sustainable Development, 12, 82-101.

Hilmersson, F. P., Hilmersson, M. (2021). Networking to accelerate the pace of SME innovations. Journal of Innovation \& Knowledge, 6(1), 43-49.

Holgersson, M. (2013). Patent management in entrepreneurial SMEs: a literature review and an empirical study of innovation appropriation, patent propensity, and motives. R\&D Management, 43(1), 21-36.

II filar: Finansowanie przedsiębiorstw. Pobrano z https://www.gov.pl/web/tarczaantykryzysowa/finansowanie-przedsiebiorstw (03.05.2021).

Jabłoński, M. M. (2013). Kształtowanie modeli biznesu w procesie kreacji wartości przedsiębiorstw (t. 10). Warszawa: Difin.

Janasz, W., Janasz, K., Prozorowicz, M., Świadek, A., Wiśniewska, J. (2002). Determinanty innowacyjności przedsiębiorstw (s. 406). Rozprawy i Studia/Uniwersytet Szczeciński. Szczecin: Wyd. Naukowe Uniwersytetu Szczecińskiego.

Janiszewska, M., Janiszewski, J. (2020). Wykorzystanie regulacji podatkowych w działalności innowacyjnej polskich przedsiębiorców, Studia BAS, 1(61), 51-73.

Kahn, K. B. (2018). Understanding innovation. Business Horizons, 61(3), 453-460.

Kardas, M. (2016). Zamówienia publiczne jako instrument polityki innowacyjnej. Zarządzanie Publiczne, (35), 32-46.

KE. (2020). Horyzont Europa: inwestycje, które kształtuja nasza przyszłość. Pobrano z https://ec.europa.eu/info/sites/info/files/horizon_europe_pl_-_inwestycje_ktore_ksztaltuja_nasza_przyszlosc.pdf (31.01.2021). 
Kopaliński, W. (2007). Słownik wyrazów obcych i zwrotów obcojęzycznych z almanachem, Warszawa: Oficyna wydawnicza Rytm.

KPMG, (2019), Wsparcie dla działalności innowacyjnej - narzędzia podatkowe. Jak przedsiębiorstwa prowadza działalność $B+R$. Pobrano z https://assets.kpmg/ content/dam/kpmg/pl/pdf/2019/03/pl-Wsparcie-dla-dzialalnosci-innowacyjnej-narzedzia-podatkowe.pdf (31.01.2021).

Kraśnicka, T. (2013). Innowacje a wyniki firm produkcyjnych. Zarządzanie i finanse, $4(1), 111-128$.

Kuratko, D. F. (2009). Introduction to entrepreneurship. Australia and UK: South-Western. Mazur-Wierzbicka, E. (2015). Działalność innowacyjna przedsiębiorstw w Polsce. Zeszyty Naukowe Małopolskiej Wyższej Szkoły Ekonomicznej w Tarnowie, 1, 97-109.

MF, (2019). Objaśnienia podatkowe ministra finansów z 15 lipca 2019 r., dotyczace preferencyjnego opodatkowania dochodów wytwarzanych przez prawa własności intelektualnej - IP BOX.

Motyka, S. (2011). Pomiar innowacyjności przedsiębiorstwa. Komputerowo zintegrowane zarządzanie, 2. 160-168.

Nasution, H. N., Mavondo, F. T., Matanda, M. J., Ndubisi, N. O. (2011). Entrepreneurship: Its relationship with market orientation and learning orientation and as antecedents to innovation and customer value. Industrial marketing management, 40(3), 336-345.

Neuhäusler, P., Frietsch, R., Schubert, T., Blind, K. (2011). Patents and the financial performance of firms-An analysis based on stock market data. Fraunhofer ISI Discussion Papers-Innovation Systems and Policy Analysis, 28, 1-30.

OECD. (2018). Guidelines for Collecting, Reporting and Using Data on Innovation, Paris-Luxembourg: OECD Publishing - Eurostat.

PARP. (2020a). Monitoring innowacyjności polskich przedsiębiorstw. Wyniki III edycja badania 2020.

PARP. (2020b). Raport o stanie sektora małych i średnich przedsiębiorstw w Polsce 2020. PE. (2020). Polityka innowacyjności. Pobrano z https://www.europarl.europa.eu/ftu/pdf/ pl/FTU_2.4.6.pdf (31.01.2021).

Pichlak, M. (2012). Otwarte innowacje jako nowy paradygmat w zarządzaniu innowacjami. Zeszyty Naukowe. Organizacja i Zarządzanie/Politechnika Śląska, 60, 281-292.

Porter, M.E., (1980). Competitive Strategy: Techniques for Analyzing Industries and Competitors. New York: The Free Press.

Porter, M.E., (1985). Cometitive Advantage Creating and Sustaining Superior Performance. New York: The Free Press.

Romanowska, M. (2016). Determinanty innowacyjności polskich przedsiębiorstw. Przegląd Organizacji, 2 (913), 29-35, 
Sawicki, P. (2019). Rozwój MSP w kontekście unijnego wsparcia w perspektywie 2014-2020-dylematy i wyzwania. Zeszyty Naukowe ZPSB Firma i Rynek, 1 (55), 49-64.

Schippers, M. C., West, M. A., Dawson, J. F., (2015). Team Reflexivity and Innovation: The Modera-ting Role of Team Context. Journal of Management, 41/3, 769-788.

Schumpeter, J.A. (1960). Teoria rozwoju gospodarczego. Warszawa: PWN.

Seru, A. (2014). Firm Boundaries Matter: Evidence from Conglomerates and R\&D Activity. Journal of Financial Economics, 111 (2), 381-405.

Sobolewski, H., \& Wściubiak, Ł. (2017). Innowacje a wyniki przedsiębiorstwa: wybrane aspekty badawcze. Finanse, Rynki Finansowe, Ubezpieczenia, 85, 433-441.

Stawicka, M. (2017). Bariery innowacyjności małych i średnich przedsiębiorstw w Polsce. Journal of Modern Science, 33(2), 247-260.

Szczepaniak, I. (2009). Rola małych i średnich przedsiębiorstw w gospodarce (na przykładzie przemysłu spożywczego). Equilibrium. Equilibrium. Quarterly Journal of Economics and Economic Policy, 2(1), 71-81.

Wiśniewska, J. (2018). Aktywność innowacyjna przedsiębiorstw w Polsce na tle Unii Europejskiej. Marketing i Rynek, 9 (CD), 982-995.

www.bloomberg.com

Zegarowicz, Ł. (2016). Ulga na B+ R-ocena zmian w zakresie podatkowego wsparcia działalności innowacyjnej w Polsce. Optimum. Economic Studies, 84(6), 123-141.

Ziętek-Kwaśniewska, K. (2020). Nakłady na działalność badawczorozwojową w Polsce na tle państw Unii Europejskiej. Studia BAS, (1), 9-25.

Zimmerling, A., Chen, X. (2021). Innovation and possible long-term impact driven by COVID-19: Manufacturing, personal protective equipment and digital technologies. Technology in Society, 65, 101541.

Zuzek, D. K., Paluch, Ł. (2016). Wpływ działalności innowacyjnej na konkurencyjność sektora małych i średnich przedsiębiorstw w Polsce. Marketing i Rynek, 10, 632-642.

\section{Streszczenie}

Sektor małych i średnich przedsiębiorstw stanowi kluczowy element polskiej gospodarki. W związku z tym głównym celem polityki gospodarczej państwa powinno być podnoszenie potencjału innowacyjnego MSP. Kluczową rolę w tym zakresie odgrywają narzędzia polityki fiskalnej, takie jak dotacje, ulga B+R, Innovation Box i zamówienia publiczne. Duże znaczenie dla finansowania działań innowacyjnych MSP mają fundusze unijne. Celem pracy jest przedstawienie pojęcia innowacji oraz podkreślenie ich roli w funkcjonowaniu przedsiębiorstwa na konkurencyjnym rynku. Scharakteryzowano sektor MSP w Polsce. Przede wszystkim skupiono się na narzędziach polityki fiskalnej wspierających innowacyjność tego sektora. W pracy wykorzystano analizę literatury oraz raporty dotyczące MSP w Polsce. Wyniki przeprowadzonych badań wskazują, ze zarówno 
władze unijne, jak i polskie zauważają potrzebę wspierania działalności innowacyjnej MSP, stosując m.in. narzędzia polityki fiskalnej. Pomimo tego poziom innowacyjności tych przedsiębiorstw jest stosunkowo niski, a znajomość zachęt finansowych niewielka.

SŁowA KLUCzowe: innowacje, MSP, ulga B+R, IP Box.

\section{Summary}

The sector of small and medium-sized enterprises is a key element of the Polish economy. Therefore, the main goal of the state's economic policy should be to increase the innovative potential of SMEs. Fiscal policy tools such as subsidies, R\&D tax relief, Innovation Box and public procurement play a key role in this scope. EU funds are of great importance for financing innovative activities of SMEs. The aim of this work is to present the concept of innovation and to emphasize its role in the functioning of the company on a competitive market. The sector of small and medium-sized enterprises in Poland was characterized. First of all, epmphasis was placed on fiscal policy tools supporting innovation in the SME sector. The study uses literature analysis and reports on small and medium-sized enterprises in Poland. The results of the research show that both the EU and Polish authorities notice the need to support innovative activities of small and medium-sized enterprises by using i.a. fiscal policy tools. Despite this, the level of innovation of these enterprises and the knowledge of financial incentives are relatively low.

KEYwords: innovation, SME, R\&D tax relief, IP Box.

\section{Nota o autorze}

Katarzyna Szuper - mgr, doktorantka na Wydziale Ekonomicznym Uniwersytetu Marii Curie-Skłodowskiej w Lublinie; główne obszary działaności naukowej: finanse przedsiębiorstw, innowacyjność, globalizacja, międzynarodowe stosunki ekonomiczne; e-mail: katarzyna.szuper@live. umcs.edu.pl; ORCID: 0000-0003-4191-336X. 